\title{
Effect of inhaled frusemide on the early response to antigen and subsequent change in airway reactivity in atopic patients
}

\author{
Paolo Verdiani, Stefania Di Carlo, Aldo Baronti, Sebastiano Bianco
}

\begin{abstract}
The purpose of this study was to investigate whether inhaled frusemide was able to inhibit the increase in nonspecific bronchial reactivity that occurs after the early response to allergen exposure in subjects with allergic rhinitis or asthma (or both). Ten symptom free patients initially underwent a challenge with methacholine, to determine the dose of methacholine that caused a $15 \%$ fall in FEV (PD $_{15}$ FEV $_{1}$ meth) and a challenge with a specific allergen, to determine the concentration of allergen that caused a fall in $\mathrm{FEV}_{1}$ of at least $15 \%$. On two further occasions they inhaled allergen concentration that had caused the $\geqslant 15 \%$ fall in $F E V_{1}$ preceded by inhaled frusemide $(40 \mathrm{mg}$ frusemide in $4 \mathrm{ml}$ buffered saline) or placebo ( $4 \mathrm{ml}$ of diluent solution), according to a randomised, double blind, crossover design. All allergen studies were separated by at least seven days. A methacholine challenge was performed two hours after the allergen challenge, a time when the early response to allergen had completely resolved. Frusemide inhibited the early response to antigen, causing mean (95\% confidence interval) protection of $87.6 \%(96-80 \%)$ for the maximum fall in $\mathrm{FEV}_{1}$. The increase in non-specific airway reactivity that occurred after antigen when this was preceded by placebo was reduced by frusemide. The mean $(95 \% \mathrm{CI})$ difference in $\mathbf{P D}_{15}$ values between the placebo and the frusemide days was $1.73(2 \cdot 30-$ 1.16) doubling doses of methacholine. These results confirm that frusemide is highly effective in preventing the early response to allergen, and show that it inhibits the increase in reactivity to methacholine that follows the early response.
\end{abstract}

A single exposure to antigen, as in an antigen challenge test, is capable of inducing an increase in non-allergic bronchial responsiveness. 'This phenomenon was thought to be related to the late response to antigen, ${ }^{2}$ though recent studies have shown that nonspecific reactivity increases soon after the early response and some hours before the onset of the late response. ${ }^{34}$
Frusemide, a drug widely used for its natriuretic properties, has been shown, when given by inhalation, to provide substantial protection against bronchoconstriction induced by various stimuli, ${ }^{56}$ including allergen exposure in sensitised individuals. ${ }^{78}$

In subjects with allergic asthma and early and late asthmatic responses to inhaled allergen frusemide, inhaled before the allergen challenge, reduced the early and late response to antigen but did not protect against the increased airway reactivity to methacholine seen 24-30 hours after inhalation of antigen. ${ }^{7}$ Our study was designed to investigate whether frusemide, in addition to suppressing the early response to antigen, prevents the increase in airway responsiveness to methacholine that occurs two hours after the antigen challenge.

\section{Methods}

SUBJECTS

Ten patients (eight men and two women, aged 14-40 years) participated in the study after giving informed consent. All had a previous diagnosis (based on symptoms and previous treatment) of allergic rhinitis or asthma, or both, positive immediate antigen skin test responses (Alpha test, Dome/Hollister-Stier, Bayropharm Italiana, Milan), a serum concentration of total IgE of 200 IU or more (immunofluorimetric method, IgE FAST-Plus, $3 \mathrm{M}$ Baxter, Trieste), and positive results in immunoenzymatic serological tests for specific IgE antibodies (Phadezyme, Pharmacia Diagnostics, Milan) against Dermatophagoides pteronyssinus (eight patients) or grass pollen (two patients). All subjects had normal pulmonary function on admission $\left(\mathrm{FEV}_{1} 80 \%\right.$ of predicted or above), had no current symptoms, and had taken no medicine for at least four weeks before the study. All had an early response to antigen challenge $\left(\triangle \mathrm{FEV}_{1}\right.$ $>15 \%$ ).

\section{PROVOCATION TESTS}

Varying dilutions of antigen for the provocation tests were prepared by dissolving lyophilised allergen extract (Alpha Base, Dome/ Hollister-Stier, Bayropharm Italiana, Milan) in phosphate buffered saline. Fresh solutions were made each day. Acetyl- $\beta$-methacholine chloride (Sigma Corporation, St Louis, Missouri) was provided in powdered form by Mascia Brunelli (Milan) and prepared in con- 
centrations of $0.4 \%$ and $4 \%$ in buffered saline. Two $2 \mathrm{ml}$ vials of frusemide $10 \mathrm{mg} / \mathrm{ml}$ (Lasix, approved for intravenous administration) or placebo (a diluent solution consisting of sodium chloride $28.0 \mathrm{mg}$, sodium hydroxyl to reach $\mathrm{pH} \mathrm{9,} \mathrm{and} \mathrm{water} \mathrm{to} \mathrm{make} \mathrm{up} 4 \mathrm{ml}$ ) matched for osmolarity $(295 \mathrm{mmol} / \mathrm{kg})$, which was kindly provided by Hoechst Italia Sud, L'Aquila, were used for aerosol delivery.

Methacholine aerosol was generated by a de Vilbiss nebuliser attached to a dose metering device (breath activated solenoid valve, timing circuit, and compressed air source) and delivered for 0.6 second during slow, deep inspirations from functional residual capacity to total lung capacity. With this method the mean volume output of the nebuliser was 0.01 (SD 0.001$) \mathrm{ml}$ per breath. Aerosols of allergen, frusemide, and placebo were delivered via a jet nebuliser (Nebula, Markos, Monza, Italy), $4 \mathrm{ml}$ aliquots of allergen solution, frusemide, and placebo being used. During the 20 minutes when patients inhaled frusemide or placebo from the nebuliser the mean weight of frusemide delivered to the mouth (calculated on five occasions by differential weighing after placing $4 \mathrm{ml}$ frusemide solution in the reservoir) was 28.3 (SEM 0.6) $\mathrm{mg}$. The same nebuliser was always used for all tests in an individual patient.

$\mathrm{FEV}_{1}$ was measured with a HewlettPackard Pulmonary System (HP 47804A), which consists of a pneumothacograph (Fleisch No 3) interfaced through an A-D converter with a digital computer. The best of at least three reproducible attempts was recorded.

A bronchial provocation test with methacholine was performed according to the recommendations of the working group of the Società Italiana per la Patofisiologia Respiratoria. ${ }^{9} \quad \mathrm{FEV}_{1}$ was measured after patients had inhaled three doses of buffered saline solution. Subjects then inhaled increasing doses of methacholine, ranging from 40 to $4000 \mu \mathrm{g}$, and $\mathrm{FEV}_{1}$ was measured two minutes after each dose. The procedure was stopped when the $\mathrm{FEV}_{1}$ fell by $15 \%$ from the postsaline $\mathrm{FEV}_{1}$. Dose-response curves were constructed by plotting the fall in $\mathrm{FEV}_{1}$ from the postsaline control value against the cumulative dose of methacholine on semilog paper. $\mathrm{PD}_{15} \mathrm{FEV}_{1}$ meth was determined by linear interpolation.

Subjects underwent antigen provocation only if baseline $\mathrm{FEV}_{1}$ was greater than $80 \%$ predicted. With a nose clip applied, the patient inhaled a normal saline solution for two minutes, breathing tidally through a mouthpiece. $\mathrm{FEV}_{1}$ was measured immediately afterwards, and if it differed by less than $5 \%$ from baseline the patient started to inhale allergen, increasing by doubling concentrations from 5 activity units RAST(AUR)/ml. $\mathrm{FEV}_{1}$ was measured immediately after each inhalation, and after a further five, 10, 15, and 20 minutes. Increasing concentrations of antigen were given until the $\mathrm{FEV}_{1}$ had fallen by $15 \%$ or more from the postsaline value. The concentration of allergen required to produce a fall of at least $15 \%$ in $\mathrm{FEV}_{1}$ was recorded. This same concentration was then delivered by aerosol for two minutes on the two trial days.

\section{STUDY DESIGN}

Each subject attended the laboratory on four days. A methacholine challenge was performed on the first day and a specific allergen challenge on the second, to establish the provocative concentration of allergen that caused a fall in $\mathrm{FEV}_{1}$ of at least $15 \%$. The patient then started the formal trial after seven to 10 days. The study was performed according to a randomised, double blind, crossover, placebo controlled design. Patients attended on two days, at the same time of day, at least a week apart. After measurement of baseline $\mathrm{FEV}_{1}$ the patient inhaled frusemide or diluent solution for 20 minutes; the $\mathrm{FEV}_{1}$ was then measured again and followed immediately by inhalation of the previously determined provocative concentration of allergen that caused a fall in $\mathrm{FEV}_{1}$ of $15 \%$ or more. Antigen was delivered by aerosol for two minutes. $\mathrm{FEV}_{1}$ was measured immediately after allergen administration, and after a further five, 10,15 , and 20 minutes. The patient was then allowed to rest. The FEV 1 was measured two hours after the end of the allergen inhalation. If the $\mathrm{FEV}_{1}$ was above $95 \%$ of the baseline value, the patient underwent a methacholine provocation test. The timing of the initial methacholine challenge was arranged so that all three methacholine challenges were performed at the same time on each day. At the end of each study day subjects were questioned about side effects. They were also asked specifically about development of cough, wheezing, or breathlessness six to eight hours after the allergen challenge and during the night and following days.

\section{STATISTICAL ANALYSIS}

The protective effect of frusemide on the early response to antigen was calculated as a percentage for each patient according to the formula (placebo - frusemide)/placebo $\times$ 100 , on the basis either of the area under the time-response curve of the change from baseline (AUC) or of the maximum fall in FEV five to 20 minutes after challenge expressed as percentage of the value at time zero. Methacholine $\mathrm{PD}_{15}$ values were logarithmically transformed to stabilise group variance before analysis. The change between placebo and frusemide values of methacholine $\mathrm{PD}_{15}$ was calculated in terms of doubling doses for each subject.

Comparison of multiple groups was performed by the use of two way analysis of variance combined with the least significant difference method. ${ }^{10}$ The Paired Student's $t$ test was used to compare differences between two groups. A p value of 0.05 or less for two tailed comparison was considered significant. Unless stated otherwise data are expressed as means and $95 \%$ confidence intervals $(\mathrm{CI})$. 


\section{Results}

Baseline $\mathrm{FEV}_{1}$ on the two study days was similar to the values recorded during the preliminary challenge test. There were no significant differences in $\mathrm{FEV}_{1}$ values before and after placebo and frusemide treatment on the two study days (table 1 ).

\section{RESPONSE TO ANTIGEN}

After treatment with placebo all the patients had an early response to the antigen challenge, with a maximum fall in $\mathrm{FEV}_{1}$ from baseline of $17 \cdot 3^{\circ}$ o $\left(95^{\circ}\right.$ o CI $\left.12 \cdot 5-22 \cdot 1^{\circ}{ }_{0}\right)$; this was significant five, 10, 15 and 20 minutes after challenge (figure).

After treatment with inhaled frusemide the airway response to allergen was substantially reduced; $\mathrm{FEV}_{1}$ did not differ significantly from baseline values at any time after challenge (figure). The maximum fall in $\mathrm{FEV}_{1}$ from baseline was $2 \cdot 0^{\circ}{ }_{0}\left(0 \cdot 7-3 \cdot 3^{\circ}{ }_{0}\right)(\mathrm{p}<0.01$ in the comparison with placebo)-significantly lower than the fall after placebo at all time points up to 20 minutes after challenge ( $p<0.001$ ). The mean protection afforded by frusemide was $88^{\circ}{ }_{0}\left(96-80^{\circ}{ }_{0}\right)$ for the maximum fall in $\mathrm{FEV}_{1}$ and $93^{\circ}{ }_{0}\left(115-71^{\circ}{ }_{0}\right)$ for the area under the time-response curve.

Table 1 Mean (SD) values of FEV , before and immediately after inhaled frusemide and placebo and two hours after allergen challenge (immediately before methacholine challenge)

\begin{tabular}{llll}
\hline & \multicolumn{3}{l}{$F E V_{l}(l)$} \\
\cline { 2 - 4 } & \multicolumn{2}{l}{ Frusemide } & \multicolumn{2}{l}{ Placebo } \\
\hline Baseline & $3.65(0.70)$ & 3.66 & $(0.68)$ \\
After premedication & $3.67(0.72)$ & 3.62 & $(0.67)$ \\
Two hours after challenge & $3.69(0.66)$ & 3.63 & $(0.72)$ \\
\hline
\end{tabular}

RESPONSE TO METHACHOLINE AFTER ANTIGEN

Two hours after antigen challenge recovery was complete on both study days, and there were no differences in $\mathrm{FEV}_{1}$ on the frusemide and placebo days before the methacholine challenge.

There was wide intersubject variability in the bronchial response to methacholine in the preliminary test (table 2). All patients showed a substantial increase in bronchial reactivity to methacholine two hours after antigen exposure when this was preceded by placebo. The increase was inhibited by frusemide. The mean difference in $\mathrm{PD}_{15}$ values between placebo and frusemide was $1.73(2 \cdot 30-1 \cdot 16)$ doubling doses of methacholine. The degree of protection was not affected by the order of treatments.

Five subjects reported cough and shortness of breath several hours after the initial antigen challenge. The same delayed symptoms followed the antigen challenge after placebo; they were prevented by frusemide pretreatment.

No subject experienced any side effect after inhaled frusemide; in particular, none reported any increase in diuresis.

\section{Discussion}

In our atopic patients frusemide, administered by aerosol, provided strong protection against antigen induced bronchoconstriction. This confirms the results of previous studies, carried out under similar experimental conditions. ${ }^{78}$ The results of the trials differ only quantitatively, in that in the current study frusemide caused almost complete protection against antigen challenge, whereas in the former studies it caused substantial attenuation, but did not suppress the airway response to allergen completely. This may be because we

$\mathrm{FEV}_{1}(\mathrm{l})$

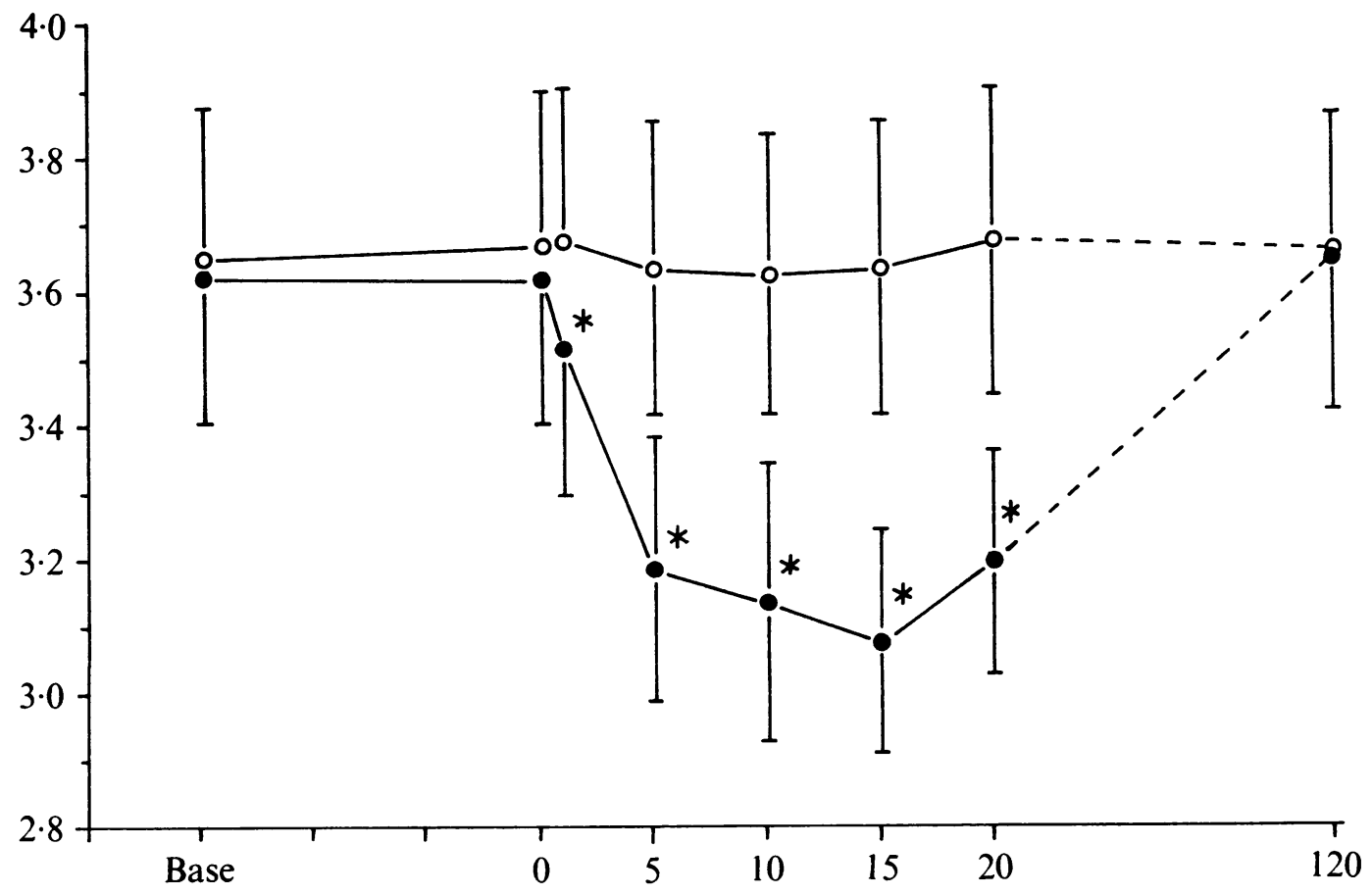

Time after challenge (minutes)

Change in FEV, after antigen challenge and treatment with either frusemide ( $\bigcirc-0$ ) or subjects with allergic rhinitis or asthma or both. * Significant difference ( $p<0.001)$ between $F E V$, after frusemide and after placebo. 
Table 2 Individual and geometric mean $(95 \% C I) P D_{15}(\mu \mathrm{g})$ for the three methacholine challenges

\begin{tabular}{llcc}
\hline & $\begin{array}{l}\text { Initial } \\
\text { methacholine } \\
\text { challenge }\end{array}$ & \multicolumn{2}{l}{ Methacholine challenge 2 } \\
\cline { 3 - 4 } Patient No & diluent & frusemide \\
\hline 1 & 1669 & 728 & 1669 \\
2 & 1313 & 257 & 1130 \\
3 & 2591 & 706 & 916 \\
4 & 796 & 361 & 1086 \\
5 & 1002 & 265 & 1261 \\
6 & 1261 & 488 & 1436 \\
7 & 185 & 61 & 166 \\
8 & 713 & 61 & 424 \\
9 & 584 & 1326 & 561 \\
10 & 3197 & 259 & 3984 \\
Geometric mean & 1035 & $(112-602)$ & 939 \\
$\left(95^{\prime}{ }_{0}\right.$ CI) & $(579-1850)$ & & $(509-1737)$ \\
\hline
\end{tabular}

induced milder bronchoconstriction with antigen in the present study.

After placebo all our patients showed a substantial increase in non-allergic bronchial reactivity two hours after the allergen challenge. Frusemide pretreatment, in addition to suppressing the early response to antigen, inhibited this rise of non-specific reactivity.

As frusemide does not attenuate methacholine induced bronchoconstriction when not preceded by antigen, probably the mechanisms by which frusemide reduces the early response to antigen and the subsequent hyperresponsiveness to methacholine are intimately connected.

In the past few years convincing evidence has accumulated to suggest that the increase in non-allergic bronchial responsiveness after antigen exposure is restricted to the patients who develop a late response to antigen; so it was assumed to develop after the late response and measurements of non-specific reactivity were generally performed eight or more hours after antigen exposure. The results of two recent studies, however, led to different conclusions. Durham et al found a substantial increase in histamine reactivity in 14 asthmatic subjects three hours after an antigen challenge ${ }^{4}$; Thorpe and his coworkers ${ }^{3}$ found substantially increased reactivity to histamine shortly after the early response to antigen in patients with allergic asthma who had a dual response to antigen; this was seen when the early response had resolved, 45-105 minutes after inhalation of antigen. Our results confirm that there is an appreciable increase in airway reactivity to methacholine two hours after antigen challenge.

In a previous study ${ }^{7}$ frusemide, inhaled as a single dose before the antigen challenge, attenuated both the early and the late components of the dual asthmatic response but did not alter the airway response to methacholine measured 24-30 hours after antigen exposure. In our study frusemide completely blunted the early increase in non-specific reactivity. In our previous study ${ }^{7}$ the protection afforded by frusemide against the late bronchoconstrictor response to antigen was slightly less than the protection against the early response. Repeated inhalations of frusemide during an antigen study may differ from a single dose before antigen challenge in its effect both on the late response to antigen and on non-specific reactivity assessed 24 hours after allergen exposure.

The active ion transport that occurs at the level of surface cells, accounts for the electrical characteristics of airway epithelium. ${ }^{12}$ We may reasonably suggest that frusemide, by inhibiting ion transport across tracheobronchial epithelial cells, can modify transmucosal electrochemical gradients. Inhibition of chloride secretion by frusemide has been found in vitro in canine tracheal epithelium ${ }^{13}$ and in cultured tracheal epithelial cells. ${ }^{14}$ If similar changes occur in man in vivo, they might modify the function of airway epithelium, and hence lessen the airway response to stimuli such as inhaled allergen.

Mechanisms other than modification of the ionic environment of the epithelium should also be considered. Inhibition of the early response by frusemide raises the possibility that inhibition of mediator release might be important. The osmolarity of airway periciliary fluid may affect the function of effector cells, such as mast cells, which play an undoubted part in the pathogenesis of allergic airway disorders. ${ }^{15}$ Activation of pulmonary mast cells has been shown in atopic, asthmatic, and nonasthmatic subjects after bronchoalveolar challenge, ${ }^{16}$ and hyperosmotic stimuli have been shown to be capable of both inducing mediator release by mast cells and enhancing their activation in response to allergen exposure. ${ }^{1718}$ The possibility that frusemide is indirectly affecting inflammatory cell function by influencing ion and water movements across the airway epithelium cannot therefore be excluded.

In conclusion, our study confirms that frusemide provides strong protection against allergen induced bronchoconstriction in atopic patients. It also inhibits the enhancement of non-allergic bronchial reactivity that occurs shortly after resolution of the early response.

1 Cockcroft DW. Mechanism of perennial allergic asthma. Lancet 1983;ii:253-6.

2 Larsen GL. Late phase reactions: observations on pathogenesis and prevention. J Allergy Clin Immunol 1985;76: esis and

3 Thorpe JE, Steinberg D, Bernstein IL, Murlas CG. Bronchial reactivity increases soon after the immediate response in dual-responding asthmatic subjects. Chest 1987;91:21-5.

4 Cookson WOCM, Craddock CF, Benson MK, Durham SR. Falls in peripheral eosinophil counts parallel the late asthmatic response. Am Rev Respir Dis 1989;139:458-62.

5 Robuschi M, Vaghi A, Gambaro G, Spagnotto S, Bianco S. Inhaled furosemide is highly effective in preventing Inhaled furosemide is highy [abstract]. Am Rev Respir Dis 1988;137(2):412.

6 Bianco S, Robuschi M, Vaghi A, Pasargiklian M. Prevention of exercise-induced bronchoconstriction by inhaled frusemide Lancet 1988;ii:252-5.

7 Bianco S, Pieroni MG, Refini RM, Rottoli L, Sestini P. Protective effect of inhaled furosemide on allergenProtective effect of inhaled furosemide on allergen-
induced early and late asthmatic reactions. $N$ Engl J Med induced early and

8 Robuschi M, Pieroni M, Refini M, et al. Prevention of antigen induced early obstructive reaction by inhaled furosemide in (atopic) asthmatics and (actively sensitised) guinea pigs. $J$ Allergy Clin Immunol (in press).

9 Gruppo di Lavoro per la Normalizzazione dei Tests di Provocazione Bronchiale Aspecifica. Protocollo per l'esecuzione del test di provocazione bronchiale aspecifica. Fisiopatol Respir 1982;3:3-15.

10 Snedecor GW, Cochran WG. Statistical methods. 7th ed. 
Ames: Iowa University Press, 1980.

11 Vaghi A, Robuschi M, Chilaris N, Bianco S. Inhaled furosemide does not attenuate the bronchial response to methacholine in asthmatics [abstract]. Twenty third annual meeting, Societas Europaea Physiologiae Clinicae Respiratoriae, Athens 1988:8S.

12 Olver RE, Davis B, Marin MG, Nadel JA. Active transport of $\mathrm{Na}+$ and $\mathrm{Cl}$ - across the canine tracheal epithelium in

13 Welsh MJ Inhibition of

elsh MJ. Inhibition of chloride secretion by frusemide in canine tracheal epithelium. J Membr Biol 1983;71:219-26.

14 Widdicombe JH. Ion transport by tracheal epithelial cells in culture. Clin Chest Med 1986;7:299-305.

15 Holgate ST, Hardy C, Robinson C, Agius RM, Howarth $\mathrm{PH}$. The mast cell as a primary effector cell in the pathogenesis of asthma. J Allergy Clin Immunol 1986;77: 274-82.

16 Wenzel SE, Fowler AA III, Schwartz LB. Activation of pulmonary mast cells by bronchoalveolar allergen challenge. In vivo release of histamine and tryptase in atopic subjects with and without asthma. Am Rev Respir atopic subjects with and without asthma. Am Rev Respir

17 Eggleston PA, Kagey-Sobotka A, Schleimer RP, Lichtenstein LM. Interaction between hyperosmolar and IgEmediated histamine release from basophils and mast cells. Am Rev Respir Dis 1984;130:86-91

18 Silber G, Proud D, Warner J, Naclerio R, Kagey-Sobotka A Lichenstein L, Eggleston PA. In vivo release of inflammatory mediators by hyperosmolar solutions. Am Rev Respir Dis 1988;137:606-12. 